UNIVERSITY OF CHITRAL JOURNAL OF LINGUISTICS AND LITERATURE

VOL. 1 | ISSUE I | JULY - DEC | 2017

ISSN (E): 2663-1512, ISSN (P): 2617-3611

\title{
On Gulzar's Poetry: Comparing the Three Versions of English Translation
}

\section{Pallavi Kiran}

Assistant Professor (English), School of Humanities, KIIT Bhubaneswar, Odisha, India pallavi.kiranfhu@kiit.ac.in

\begin{abstract}
Gulzar's merit as a contemporary Indian poet rests on his use of Hindustani, which has a high degree of emotional intensity, expressiveness, naturalness and unusual vividness that strikes the head and the heart of the listener. The study pragmatically and stylistically probes a randomly selected poem of Gulzar and its English translation by three translators, underlining, in the main, the variations in the linguistic choices they make and the significant differences in their translation. The analysis discusses that which is complicated and complex in the poem; and how it is simplified by the translator, leaving out that which puzzles the poet. The pragmatic-stylistic approach effectively identifies the translation shifts and investigates the value and belief system of Gulzar encoded in the language.
\end{abstract}

Keywords: Gulzar, Poetry, Hindustani, English translation, Pragmatic-Stylistic approach, Poetry Translation Evaluation.

\section{Introduction}

Gulzar has made such an immense contribution to Hindustani poetry in the past three decades that its worth is being realized in the $21^{\text {st }}$ century. Breaking the shackles of the classical Urdu poetry tradition and following the style of free verse, he has enriched the realm of IndianUrdu poetry by his sense and sensibility of poetic images. Pavan K. Varma comments on his sense of imagery thus, "The uniqueness of Gulzar's verse is that it is luminescent with imagery that is startling as it is beautiful. He has the ability to juxtapose a thought with an image so powerful that a reader is literally wrenched out of his or her world." (Varma (trans.) xiv)

Some of his poetic works have been translated into English, in India and abroad. These include Autumn Moon (1999), Silences: Selected Poems (1994), Selected Poems (2012), Neglected Poems (2013), Green Poems (2014), Suspected Poem (2017), 100 Lyrics (2012), Another 100 Lyrics (2016), and Pluto (2015). English translations have heightened (up) his literary presence. Though the translations have existed for decades and attracted a large audience at the home as well as overseas, these have not received adequate academic attention. The study, therefore, seeks to draw attention to, and evaluate, English translations of Gulzar's poetry to find out what is transferred, how it is transferred and how much is transferred. For the purpose, a poem is randomly selected along with its English version by different translators to compare and contrast the balance between the two versions. 
UNIVERSITY OF CHITRAL JOURNAL OF LINGUISTICS AND LITERATURE

VOL. 1 | ISSUE I | JULY - DEC | 2017

ISSN (E): 2663-1512, ISSN (P): 2617-3611

\section{Gulzar's Poetry}

Raising the Hindustani poetry to a higher level, Gulzar complements his thoughts and emotions through his unusual imagery. Saba Mahmood Bashir comments on his poetry skills, "while usual and mundane, images strike an immediate chord with the reader/common audience, mixing it with an unusual poetic image enhances its aesthetic value while keeping the reader grounded with the images he is familiar with," (Bashir 61). Moreover, in an interview with her, he lists out the names of the poets such as T. S. Eliot, Rabindranath Tagore, Bulleh Shah, Farid, Sant Tukaram and Namdev that influenced and shaped his poetic cult. He develops a great deal of poetry that is new and original in his collections namely, Kuch Aur Nazme (1980), Mera Kuch Saman (1994), Raat Pashmine Ki (2002), Triveni (2003), Pukhraaj (2005), Yaar Julahe (2009), Pandrah Panch Pachattar (2010), Meelo Se Din (2010), Dyodhi (2012), Pluto (2013) that showcase a variety of poetic innovation. Gulzar's poetic format of Hindi-Urdu appeals many for it is sweet and soulful.

To determine the significance of Gulzar as a contemporary poet, the study briefs out the influential poets of his time. In the context of Hindustani poetry. Among them, "the name of Ghalib stands foremost." (Qadir 18) Ghalib's poetry absorbs the words and expressions of Urdu and Persian. His poems enrich the colloquialism and simplify the vocabulary of Hindustani. The subject of his poetry comes from everyday philosophy, existentialism and mysteries of life that soothe(s) and delight(s) the hearts of many in their moments of pensiveness or joy. Ghalib's Ghazal revised the older Ghazal conventions from expressing only 'the pangs of love' to 'talking love' (Qadir 22). Though his couplets are easy on the tongue and witty in a sense, translating Ghalib's poems was not considered easy. While translating the couplets of Ghalib, Ralph Russell remarks, "You are forced with the stubborn and unalterable fact that Urdu has rhyming words in plenty and English has not. [...] You are forced, then, in most cases to translate a poem knit together by a unity of rhyme into one where this kind of unity cannot be maintained." (Russell 77) Sounds of the Urdu often pose difficulties for the translators. They are not only sounds, but also metaphors or symbols that denote the politeness and its subtleties.

Hindustani, the lingua Franca of North India, helped the poets of the partition period to voice the pain and agony of their region. For example, Bulleh Shah's (1680-1757) poetry occupies much of his subject from the turbulence in Punjab between Muslims and Sikhs. He writes spiritual poetry propagating the four stages of Sufism: Shariat (path), Tariqat (observance), Haqiqat (truth) and Marfat (union) that appealed to all. (Shah 2009) His verse form and style is called Kafi. Sufi singers in India and abroad still follow his style (still). However, in the English translation BullehShah-made-easy, Muzzafar G. A. Ghaffar criticises the "over simplifying the meaning of the verses in order for the uninitiated or partially initiated to make sense of them; and under mixing the need for the Punjabi literacy by offering a Romanised transliteration of the verses and their English 
UNIVERSITY OF CHITRAL JOURNAL OF LINGUISTICS AND LITERATURE

VOL. 1 | ISSUE I | JULY - DEC | 2017

ISSN (E): 2663-1512, ISSN (P): 2617-3611

translation on top of that." (Alam, "How to read Bulleh Shah.") In other words, poetry translation should not be a process of oversimplifying or under mixing of the poetic elements but the transfer of entire creative energy of the original.

During upheaval and unrest in India, the Progressive Writers Movement ${ }^{1}$, played a significant role in the development of Hindustani poetry ${ }^{2}$. Besides, using Hindustani to inspire people through writings, to preach equality and lash out at the social inequality and backwardness, it led to the unification of the art and its further beautification. Among the prominent members of the movement were Sadat Hassan Manto, Ali Jawad Zaidi, Zoe Ansari, M.D. Taseer, Faiz Ahmed Faiz and many more. Among them, Kaifi Azmi (1919-2002) introduced Hindustani poetry in Bollywood. His song 'Ab tumhare hawale watan saathiyoon' (is) still stirs up the sense of patriotism in Indians. Experiencing the menaces of communalism since childhood and the love for country since then, inclines his poetic writing. He has four anthologies to his credit namely Jhankar (1944), Akhiri Shab (1947), Awara Sajde (1974) and Iblis ki Majlis-e-Shori (1983). He verses boldly and Sajjad Zaheer refers his poems as 'simple and direct.' (2015) His poems, (are) translated into English by Pavan Kumar Varma, (that) unfortunately received(s) criticism by Anjum Hasan. She remarks, "Pavan Kr. Varma has failed to find the English language equivalents for the rhythms of Urdu." (Kidwai, "Post-Independence Urdu Poetry: the Indian Panorama.") and recommends not to struggle for capturing the rhythm of the original but to look for similar rhythms in the target language. Hindustani has its own charm and sweetness, rhythm and resonance, which should reach the English readers.

Another poet-lyricist from Delhi was Nida Fazli (1938-2016) who made most use of Hindustani to voice his separation (mostly the separation from his family during partition) and loneliness, His contribution to Bollywood was in the form of ghazal complied in his anthologies namely Safar Me Dhoop Toh Hogi, Mor Nach, Lafzo ke Phool and Ankh Aur Khawab Ke Darmiya. He writes in Hindi, Urdu, and Gujarati. Again, not much is written on the English translation of Fazli. One finds one or two translation by Komal Balraz ("Poetic Injustice") in M. Shafey Kidwai's evaluation of the Post-Independence Urdu poetry. It seems, translation is not offered to his poems yet, and hence, he is deprived of linguistic evaluation.

Another staunch poet is Amrita Pritam (1936-2004) from Punjab. She challenges the patriarchal values, redefines gender roles, and narratives assigned to women through her poetry. Defining the new femininity in the mid $20^{\text {th }}$ century, she boldly discusses the female sexuality:

"Her influencing gaze at sex, her exploration of emotional and psychological nakedness and a sense of self-irony and self knowledge underwrite several of her poems." "Amrita Pritam: Sexual Politics and Publishing in Mid $20^{\text {th }}$ Century India" ) Sunwani while briefing out the life and work of Amrita Pritam, her place in and contribution to Punjabi literature presents the fact that her works are translated in English, Albanian, Bulgarian, French, Polish, Russian, Spanish and all the 21 
UNIVERSITY OF CHITRAL JOURNAL OF LINGUISTICS AND LITERATURE

VOL. 1 | ISSUE I | JULY - DEC | 2017

ISSN (E): 2663-1512, ISSN (P): 2617-3611

Indian languages. Nirupama Dutt, a poet, writer, translator and close friend of Pritam, translates some of her works in English. Surprisingly, the translated works are still deprived of scholarly evaluation.

Thus, we see how these poets exert peculiar influence on Hindustani poetry. They bring with them the traces of literary cultures they have been through and leave behind their own literary trails. The subjects of their poetry are mainly partition, exile, society, and the love and sorrow within. Their unique poetic style shapes the understanding of Hindustani poetry and we learn about their English translations. First, the metaphors and symbols carrying the nuances and the politeness of Hindustani pose a great difficulty to the translators. Second, it must transfer the entire creative energy of the poem, which otherwise makes the translation appear as over simplified or undermixed. Third, we learn the importance of translating literary pieces immediately. The translations do not enjoy the high status more than the original, but the aim is to make the original available to the future generations. Fourth, is to make translation undergo an evaluation by the linguistic critics and scholars to locate the problems in translation and provide remedies for it. A linguistic evaluation authenticates the translation and makes the original reach the target readers as original as possible.

In this respect, the previously mentioned points project the reasons to select Gulzar's poem and his English translation for the present study. Briefing out the poetic purposes and style of the above poets justifies how Gulzar poetises in their lineage. As a contemporary, he too exerts peculiar influence and diversifies the dimensions of Hindustani poetry by conveying his deep philosophies of life and its aspects through colloquialism. His literary worth and presence is appreciated by the good amount of English translations available. Thus, the study carries out a linguistic analysis of his English translations, which will pass down his poetic style, form and fame as a poet of Hindustani to the future generation.

\title{
Methodology
}

A translation often requires a comparative analysis with the original. Therefore, the present study attempts to locate the problems in English transations by the three translators Rina Singh,J.P. Das, and Pavan Kumar Varma through an analytic approach of pragmatics and stylistics. The study deals with Gulzar's poem 'Nazm' (Selected Poems 68) and its three version of English translation by three translators namely Singh (Silences: Selected Poems. 51), Das (Autumn Moon 46), and Varma (Selected Poems 69). The original poem of Gulzar and its three translations are presented in a tabular form to make the comparison of pragmatic stylistic features easy for the readers.

\author{
Nazm \\ (Gulzar) \\ Nazm uljhi hui hai sine me
}




\section{UNIVERSITY OF CHITRAL JOURNAL OF LINGUISTICS AND LITERATURE \\ VOL. 1 | ISSUE I | JULY - DEC | 2017 \\ ISSN (E): 2663-1512, ISSN (P): 2617-3611}

Misre atke huye hai honthoon par

Lafz kagaz par baithte hi nahi

Udte firte hai titliyoon ki tarah

Kab se baitha hua hoon main, 'jaanam'

Sada kagaz par likh kar tera naam

Bas tera naam hi mukammal hai Isse behtar nazm bhi kya hogi

\begin{tabular}{|c|c|c|}
\hline (Rina Singh) & $\begin{array}{c}\text { Poem } \\
\text { (J.P.Das) }\end{array}$ & $\begin{array}{c}\text { Poem } \\
\text { (Pavan Kumar Varma) }\end{array}$ \\
\hline $\begin{array}{l}\text { A poem } \\
\text { entangled in my chest, } \\
\text { lines } \\
\text { fastened on my lips, } \\
\text { words like butterflies } \\
\text { won't sit still on paper. }\end{array}$ & $\begin{array}{l}\text { A poem is entangled in the } \\
\text { heart. } \\
\text { Lines trapped on the lips, } \\
\text { words flit about like } \\
\text { butterflies- they do not } \\
\text { settle down on the page. }\end{array}$ & $\begin{array}{l}\text { A poem is caught in my heart Its } \\
\text { lines stuck on my lips. } \\
\text { Words refuse to sit on paper. } \\
\text { They wing around like butterflies. } \\
\text { Long have I waited, my beloved, } \\
\text { To write a name on a sheet of white } \\
\text { paper. }\end{array}$ \\
\hline $\begin{array}{c}\text { I sit } \\
\text { for so long with your } \\
\text { name on this blank } \\
\text { paper. } \\
\text { Your name just your } \\
\text { name exists; could there } \\
\text { be } \\
\text { a better poem? }\end{array}$ & $\begin{array}{c}\text { I have been here for a long } \\
\text { time, my love, having written } \\
\text { your name on the blank page. } \\
\text { Isn't the poem done? } \\
\text { Can there be } \\
\text { a better poem than your name } \\
\text { itself! }\end{array}$ & $\begin{array}{l}\text { Your name is enough, complete } \\
\text { What better poem can there be? }\end{array}$ \\
\hline
\end{tabular}

Gulzar expresses the common emotions of being in love in a very uncommon way. His beloved is the obvious subject of the poem and the lines describe his experience of falling in love. He finds it difficult to focus on his poem as strong random thoughts and ideas run through his head and heart, which he explains with the analogy of butterfly. He intends to tell her how her presence in his life has filled it with grace, lightness and a sense of completeness. His poetry now is nothing other than her.

\section{Pragmatic Features}

In a whimsical state, the first line suggests how the poet is thinking of a poem but the random thoughts in his head and heart is thwarting him from doing so. The meaning is well conveyed by the phrases 'nazm uljhi hai' and 'sine me.' 'Nazm' is an Urdu word, meaning 'poem' while 'uljhi' and 'sine' are the Hindi(u)/Arabic word, meaning 'puzzled' and 'heart' respectively. The translation is close but the choice of equivalents makes the difference. For instance, Singh and 
UNIVERSITY OF CHITRAL JOURNAL OF LINGUISTICS AND LITERATURE

VOL. 1 | ISSUE I | JULY - DEC | 2017

ISSN (E): 2663-1512, ISSN (P): 2617-3611

Das use the equivalent 'entangled' to capture the image of 'uljhi' and it sounds literal. Varma, on the other hand, tries to capture the pronunciation and the tone of 'uljhi' in 'caught.' 'Caught' and 'entangled' are and so balance the pragmatic force that 'uljhi' carries in the original. Again, Das and Varma use 'heart' for 'sine me' while Singh's 'chest' sounds prosaic to the ears. 'Chest' sounds flat and plain and misses the romantic love. The difference(s) occurred in making the best selection of equivalents is mainly due to the lack of pragmatic factors involved in achieving unity and homogeneity.

Gulzar makes his poetry out of colloquialism of the present day life. The line 'misre atke huye hai hoontho par' suggests how his lines of the poem are on his lips but he cannot express.

In the Hindustani colloquialism, it is a way of saying for something that is there in one's head and heart yet is he unable to express or find exact expression. The use of relative word (related to 'nazm') 'misre' is an Urdu formal term for poetry meaning 'line of the couplet.' 'Atke' denotes being stuck in Hindi. 'Hoontho par' goes beyond the connotation and denotation suggesting how lines of the poem should flow naturally without being obstructed. For instance, in such a situation, we generally frame a sentence like 'dil me hai par zuban par nahi aa rahaa (it is there in my heart but I am unable to speak). The translators use 'lines' and 'lips' as equivalents for 'misre' and 'hoonth' that fit(s) in the translation, for the scientific and technical words are translated literally, yet it loses the contextual clue and the deviation appears with the equivalents of 'atke.' Singh uses 'fastened,' Das uses 'trapped,' and Varma uses 'stuck.' The three equivalents are again synonymous to each other yet these are different in usage. 'Fastened' means to become firmly close together; 'trapped' means to trick or device into doing something contrary to their interest or intentions; and 'stuck' means unable to move or be moved. Hence, from the contextual point of view, 'stuck' seems appropriately used in accordance with the intention, sound, and meaning, while 'fastened' fails to capture the intention, and 'trapped' is somewhat close but does not convey the aesthetic feel. Thus, there are marked differences between Hindustani and English that pose a significant difficulty to the translators in achieving an accurate lexical rendering because of the pragmatic factors.

Gulzar, further compares his 'nazm,' it's lines, and words, to butterfly and invite the readers to paint the picture of butterfly in their mind. The third line suggests how he cannot keep up with his thought process and hence cannot pen them down. 'Lafz' is related to nazm meaning 'shabd'in Hindi. 'Kaagaz' is the sheet of paper to write on. The poetic force is carried out by the phrase 'baithte hi nahi' suggests his difficulty in penning down his unguarded thoughts and flashy images into action. He sees them flying and floating in the sky like the butterflies. The Butterfly symbolizes personal transformation and the beauty of life's continuous unfolding. Hence, the obvious assumption here is of the poet falling in love. He feels being in the seventh sky, has a story to tell, incidents to relate to and (an) anecdotes to share. Yet, he finds no expressive words 
UNIVERSITY OF CHITRAL JOURNAL OF LINGUISTICS AND LITERATURE

VOL. 1 | ISSUE I | JULY - DEC | 2017

ISSN (E): 2663-1512, ISSN (P): 2617-3611

as his words seem to carry the spirit of butterflies. Translated image of 'lafz,' and 'titliyoon' have an exact rendering i.e. 'words,' and 'butterflies.' However, the shift occurs in finding correct equivalents for 'udte-firte' and the phrase 'baithte hi nahi.' Consequently, Singh misjudges the content and its context and translates it literally. Further, it seems in a haste or deliberately she drops the metaphor of 'udte-firte;' owing to non-existence of an exact equivalent. She did not try to create the nuance for the target audience as Das does. He uses 'flit' for 'udte-firte' meaning to move 'swiftly and slowly.' The equivalent relates to the swift and light movement of butterflies. However, his use of equivalent 'page' for 'kaagaz' sounds very formal and flat unlike 'paper' used by Singh and Varma. 'Page' means one or both side of the sheet of a paper in a book, magazine, newspaper etc. While 'paper' means a material used for writing, drawing or printing on. Similarly, he equates the phrase 'baithe nahi hai' with 'do not settle down' which gives a different meaning. Settling down means as if the words are at a war with each other and they do not settle in war. This is against the connotation of butterfly sitting still on one place. Nevertheless, Varma captures it intelligibly 'refuse to sit' and keeps it simple.

'Refuse' connotes the negative context in a positive way unlike 'does not sit,' read by Singh. Thus, to capture the beauty of simplicity of the diction and the complexity of metaphors, the translators should use equivalents that go well with the context.

In the following couplet (line 5\&6), addressing his beloved, 'jaanam', the poet speaks about his patience despite the restlessness he is going inside. Here he talks to her and addresses her yet does not mention her name. As a poet, he knows well what to tell and how much. He deliberately leaves out his beloved's name to keep a grip on the reader's attention and intrigue. Unfortunately, Singh drops the metaphor of 'jaanam' completely and hence the whole reference attached to it; in spite of the accurate equivalent available. While Das's use of 'my love' and Varma's use of 'my beloved,' both sounds similar and tends to carry the emphasis of 'jaanam.' Similarly, the phrase 'kab se baitha hua hoon main' suggests his willingness to wait patiently and let his thoughts find their way to his poem. 'Kab se' refers to the wait time he has passed on willingly. However, in translation, Singh equates it literally, 'for so long,' Das too equates it literally with an addition i.e. 'for a long time.' These equivalents do not match with precise meaning and the poetry it carries. Varma again stands out by keeping up the precision in using the equivalent 'long.' Further, 'baithta hua hoon' implies the state of idealness when one is lost in someone's thought and feels like doing nothing. Singh uses the phrase 'I sit/ for so long' literally. Das, on the other hand, mishandles the phrase 'I have been here,' that does not convey the state of idealness intended by the poet. Varma picks up the undertone and intelligibly creates the phrase 'long have I waited' and it covers up the entire connotation.

The last couplet reveals the apex of the poem. With the phrase 'likh kar tera naam,' he hints at all he wants to write is about her and he has so much to write that he feels puzzled and confused. 
UNIVERSITY OF CHITRAL JOURNAL OF LINGUISTICS AND LITERATURE

VOL. 1 | ISSUE I | JULY - DEC | 2017

ISSN (E): 2663-1512, ISSN (P): 2617-3611

Das and Singh keep the equivalent 'your name' literal. Unfortunately, Varma's translation is contradicting the original. His use of the phrase 'to write the name on the sheet of white paper' connotes that the poet intends to write the name of someone else, and not of his beloved, on the white paper. He loses the metaphor of 'tere naam' and the weight it carries in the poem. Further, he fails to understand that the two languages have different syntactic organization characterised by their own degree of inflection and, in making it too poetic, one often loses the image. Further, the metaphor 'sada kaagz' is the white sheet of paper that deeply symbolizes how by writing only her name on it has opened the ways for his poetic creation. 'Sada' is a Hindi word meaning white colour and it carries the cultural nuance of purity and sanctity. This refers to the sense of pure love and sense of completeness. Das and Singh mistranslated it as 'blank paper' and the equivalent is contradictory. It contradicts the two meanings i.e. if the paper is blank, how he can sit with her name on it and if her name is on it, how the paper can be blank. Hence, the translators fail to handle the ticklish sentence effectively. It hints at their unawareness of cognitive and cultural issues when translating from Hindustani to English or vice versa. Therefore, it is not enough for the translator to be only bilingual but to be bi-cultural as well.

In the last couplet (line 7\&8), the deep philosophy of Gulzar strikes the surface. The metaphor 'tera naam' continues to carry the weight and emphasis. It defines her aura, her illustrations, her beauty, and above all, the atmosphere of their love. Singh repeats the metaphor in the line break to retain the pragmatic force of this metaphor i.e. 'your name/ just your name.' Further, the use of adjective 'just' seems deliberate to balance the heaviness assigned to the original message. Das and Varma use the literal translation 'your name.' The cultural word 'mukammal' posed them a serious problem. 'Mukammal' is an adjective used in Urdu to denote perfect or complete. Gulzar presents his philosophy on the sense of completeness in love. He describes how he feels united with her and she fills the void in his life. Alternatively, he compares her to the divine almighty. Singh could not equate it with an English word nor did she try to create one again. She distorts the meaning by the addition of 'exists' which even partially does not cover up the cultural nuance. Das tries to be poetic and cover the cultural nuances with an interrogative sentence 'Isn't the poem done?' This is an instance of imitating the poem. Imitation in poetry translation challenges the poet's authenticity. Therefore, Varma does not imitate but recreates. He uses two adjectives 'enough' and 'complete' to convey the heavy pragmatic force and cultural nuance of 'mukammal' knowing the fact that an equivalent does not exists. His equivalent fits with the original and the metaphor changes to hyperbole keeping the translation close to the original.

Gulzar ends the poem by the passionate display of his emotions using the adjectives 'mukkammal' and 'behtar.' As poetry metamorphoses a poet's thinking, so does his beloved to him. He considers her, his poetry, and finds no better subject than her. Women have always been analogous to poetry for their beauty, love and compassion. The emphasis on the phrase 'isse behtar 
UNIVERSITY OF CHITRAL JOURNAL OF LINGUISTICS AND LITERATURE

VOL. 1 | ISSUE I | JULY - DEC | 2017

ISSN (E): 2663-1512, ISSN (P): 2617-3611

bhi' projects how perfect she is for his poetry. 'Behtar' is a 'Hindi/Urdu word meaning 'better' and has been translated exactly. It is a colloquial sentence in Hindustani, which means what else can be better than the thing in present. There is no direct interrogation involved. Yet, Singh and Das convert the sentence into simple interrogative to convey the whimsical tone of the poet. Das goes a step further and keeps the interrogation separate from the rest of the poem, which partially makes the long sentence unnecessary. He brings in the metaphor of 'your name' in the last line. Varma tackles the colloquialism easily by the simple addition of interrogative word 'what.' 'What' here does not ask a question, rather it provides all the answers for how she completes him and his poetry. It is the task of the translator to present the translation in a special way of using the language for its brevity and precision.

\section{Stylistic Features}

1. In the original, the lines are not divided into stanzas and the last two lines are separated by a line gap. Contrary to this, the translations are presented in a different fashion. Singh's translation is divided into three stanzas, each unfolding the inner beauty of the poem one by one. The first part projects the troubling experiences of the poet and the reasons are made obvious. The second stanza projects the reason, i.e. his falling in love. Moreover, the third stanza projects how he feels a sense of completeness with her and so finds his poem complete. With slight difference, Das keeps the seventh line, lined out to put the emphasis on how the poet feels content and complete with her name. While Varma's shows no difference.

2. The poem is written as a whole and in free verse. The translations are of free verse too but the lines are divided into cables that make them read 15 lines for Singh and Das. Varma follows the eight lines as it is.

3. The original shows minimal use of punctuation. There is only one punctuation mark i.e. a comma in the fifth line after 'main' to produce a brief pause. The next word 'jaanam' kept under quotes that convey the weight and information at the same time. The image of 'jaanam' is of the poet's beloved. As the poet does not mention the name of their lovers so does, (?) Gulzar addresses his beloved with synonymous words. There is no other punctuation mark to put a check on the reader's reading. Unlike the original, the translators make heavy use of punctuation mark. Singh makes use of commas, full stops, semicolons, and a question mark to decorate and add aesthetic elements to her poem. She even uses line breaks to convey the intended pause, which is not there in the original. Besides using similar punctuation marks, Das too uses line breaks to keep it close to the original, failing to realise that the original poem has a flow of its own. While Pavan only uses a full stop, a comma and a question mark.

However, the punctuation of 'question mark' is questionable, as the translators have mistaken to understand the colloquialism as an interrogation. 
UNIVERSITY OF CHITRAL JOURNAL OF LINGUISTICS AND LITERATURE

VOL. 1 | ISSUE I | JULY - DEC | 2017

ISSN (E): 2663-1512, ISSN (P): 2617-3611

\section{Word classifications}

\begin{tabular}{|c|c|c|c|c|c|}
\hline Noun & Pronoun & Verb & Adverb & Adjectives & Prepositions \\
\hline $\begin{array}{c}\text { Nazm } \\
\text { sine misre } \\
\text { hoontho } \\
\text { lafz kaagaz } \\
\text { titliyoon } \\
\text { jaanam naam }\end{array}$ & $\begin{array}{l}\text { main } \\
\text { tera }\end{array}$ & $\begin{array}{l}\text { uljhi atke } \\
\text { baithe } \\
\text { udte-firte } \\
\text { baitha likh }\end{array}$ & $\begin{array}{c}\text { sada better } \\
\text { kya }\end{array}$ & kab mukammal & $\begin{array}{l}\text { me, } \\
\text { par } \\
\text { pe }\end{array}$ \\
\hline $\begin{array}{l}\text { poem } \\
\text { heart lines }\end{array}$ & $\begin{array}{c}\text { my } \\
\text { its } \\
\text { they(Varma }\end{array}$ & $\begin{array}{l}\text { caught(Varma) } \\
\text { stuck(Varma) } \\
\text { refuse(Varma) }\end{array}$ & $\begin{array}{c}\text { long enough } \\
\text { (Varma) }\end{array}$ & $\begin{array}{l}\text { like complete } \\
\text { won't(Singh) }\end{array}$ & $\begin{array}{l}\text { on } \\
\text { to } \\
\text { there }\end{array}$ \\
\hline $\begin{array}{c}\text { lips } \\
\text { words } \\
\text { paper(Singh \& } \\
\text { Varma) } \\
\text { butterflies } \\
\text { beloved name } \\
\text { lines page } \\
\text { (Das) }\end{array}$ & $\begin{array}{c}\text { \&Das) } \\
\text { I } \\
\text { your (Singh) } \\
\text { itself }\end{array}$ & $\begin{array}{c}\text { sit } \\
\text { wing(Varma) } \\
\text { have waited } \\
\text { write can be } \\
\text { entangled(Singh) } \\
\text { fastened(Singh) } \\
\text { could(Singh) } \\
\text { exists(Singh) } \\
\text { trapped(Das) } \\
\text { lilt(Das) settle(Das) } \\
\text { done(Das) }\end{array}$ & $\begin{array}{c}\text { what } \\
\text { (Varma) } \\
\text { so(Singh) }\end{array}$ & $\begin{array}{c}\text { still(Singh) } \\
\text { blank(Singh } \\
\text { \& Das) } \\
\text { white } \\
\text { (Varma) }\end{array}$ & $\begin{array}{c}\text { with(Singh) } \\
\text { on(Singh) } \\
\text { this(Singh) } \\
\text { about down }\end{array}$ \\
\hline
\end{tabular}

The poet and the translators uses nouns that are familiar enough, there is nothing unique or distinctive about them and are being used colloquially. The verbs, adverbs, and adjectives lend the 
lines and the expressions their touch of excellence and quality. The pragmatic force and power and the aesthetic beauty of each phrase, expression and the lines is grown out of the poet's and the translator's use of them. The table clearly shows that the translation do not use more numbers of nouns, pronouns, verbs, adjectives, and prepositions that suggests that the translation does not simply mimic.

\section{Findings}

- Gulzar here appears as a romantic poet who keeps his language colloquial yet poetic and makes it accessible to the common readers. He mixes literary and colloquial diction with a freedom that would have been frowned in the previous generation. However, his mix does work and he has not only achieved precision but also a variegated 'speech' interesting in itself. With his Hindi-Urdu format, he tends to create a soothing effect for poetry lovers of the generation and times to come.

Pragmatic and stylistic is most applicable for poetry translation because (a) contextual synonyms (pragmatics) provide hints for the readers to relate to the message encoded in the poem to his own socio-cultural background, knowledge and experience; (b) stylistics brings out the semantic dimension to decipher the lexical relations in its complexities. Thus, the lexical relation helps to achieve cohesion and lexical cohesion are capable of conveying the pragmatic meaning effectively.

- The inappropriate uses of equivalents by the translators are due to the chain of associations that links the text to a deeper inner meaning. Das and Singh present their version that exploits the range of possibilities, crosscurrents, and nuances present in the source text through the interaction between the semantic system of the language and the cognitive environment of the target readers.

- When translating from Hindustani to English, the translator must attach great importance to context and try to make the polysemous words unambiguous with the help of the contextual clues. Both the languages have undergone different lexical evolution(s). The meanings of the words have expanded in a way that they have endowed the old words with a new meaning by means of extension or metaphor. Moreover, both the languages have their syntactic organization characterised by their own degree of inflection.

- Self-referencing is very much evident in the three translators that coincides with the primary voice of the poet. For instance, Singh's repetition for creating the metaphor of 'mukammal' and ignoring the pragmatic force of 'udte-firte.' Das, on the other hand, makes an interrogative sentence to approximate equivalence on the level of poetry. Varma, though keeps the translation 
UNIVERSITY OF CHITRAL JOURNAL OF LINGUISTICS AND LITERATURE

VOL. 1 | ISSUE I | JULY - DEC | 2017

ISSN (E): 2663-1512, ISSN (P): 2617-3611

close, yet over-determines the context of finding the perfect subject for the poet's poetry. Thus, self-referencing makes the translators to displace the cultural embedding of the original.

\section{Conclusion}

To conclude, Singh, Das, and Varma have omitted, added and recreated the Gulzar's poem in English deviating from the original. Das and Singh have done most of the addition and omission trying to keep the style and the form of the original. Consequently, important metaphors are dropped and replaced with adjectives to fill the gaps. While Varma's translation recreates the cultural nuances and the metaphors effectively but makes a blunder by using an interrogative mark for a heightened emotional expression. That which is complicated and the translators, leaving out what, have simplified complex is otherwise puzzling. However, Varma's translation stands out by keeping close to the original while Das' and Singh's translations fail to balance the pragmatic force of the metaphors. Besides, there is no significant difference among them in the application of their translation strategies. The systematic linguistic theory employed for the identification of the translation shifts are effective tool kits applied to investigate the value and belief system of Gulzar encoded in the language.

\section{Works Cited}

"Amrita Pritam: Sexual Politics and Publishing in Mid-20th Century India." VIDA: Women in Literary Arts, 25 Feb. 2016, www.vidaweb.org/amrita-pritam-sexual-politicsandpublishing-in-mid-20th-century-india/.

"Poetic Injustice." The Hindu, The Hindu:Online Edition of India's National Newspaper, 17 June 2001, www.thehindu.com/2001/06/17/stories/1317017n.htm

Alam, Muhammad Badar. "How to Read Bulleh Shah.” DAWN.COM, 1 Jan. 2017, www.dawn.com/news/1305772

Bashir, Saba Mahmood. . "Roh Dekhi Hai Kabhi, Roh Ko Mehsus Kiya Hai? (The Imagery)." I Swallowed the Moon: the Poetry of Gulzar. HarperCollins Publishers India, 2013. "Bulleh Shah." Sufi Poetry, 26 Nov. 2009, sufipoetry.wordpress.com/poets/bulleh-shah/.

Gulzar. Autumn Moon. (J.P.Das, Trans.). New Delhi: Rupa \& Co. 1999.

Gulzar. Selected Poems. (P.K. Varma, Trans.) New Delhi: Penguin Books India. 2008. Gulzar. Silences: Selected Poems. (Rina Singh, Trans.). New Delhi: Rupa \& Co. 2013.

Kidwai, M. Shafey. "Post-Independence Urdu Poetry: the Indian Panorama." Indian Literature. Vol.45. No.5 (205). New Delhi: Sahitya Akademi. Sept-Oct, 2001. pp.19-33.

Qadir, Abdul. "Ghalib as a Poet." Famous Urdu Poets and Writers. New Delhi: Seemant Prakashan. 27 February, 2008.
Russell,
Ralph.
“On
Translating
Ghalib." 
UNIVERSITY OF CHITRAL JOURNAL OF LINGUISTICS AND LITERATURE

VOL. 1 | ISSUE I | JULY - DEC | 2017

ISSN (E): 2663-1512, ISSN (P): 2617-3611

Mahfil. Asian Studies Centre: Michigan State University. 1968-69. pp. 71-88.

Siddiqui, Mohammad Asim. "A Poet, a Revolutionary.” The Hindu, The Hindu, 29 Mar.

2016, www.thehindu.com/features/friday-review/a-poet-a-

revolutionary/article7586498.ece.

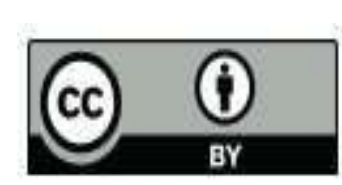

@ 2017 by the author. Licensee University of Chitral, Journal of Linguistics \& Literature, Pakistan. This article is an open access article distributed under the terms and conditions of the Creative Commons Attribution (CC BY) (http://creativecommons.org/licenses/by/4.0/). 